\title{
The European Commission's Expert Groups: Adapting to the Contestation of Expertise
}

Citation for published version (APA):

Radulova, E., Spendzharova, A., \& Breuer, J. (2020). The European Commission's Expert Groups: Adapting to the Contestation of Expertise. In V. Abazi, J. Adriaensen, \& T. Christiansen (Eds.), The Contestation of Expertise in the European Union Palgrave Macmillan. European Administrative Governance https://doi.org/10.1007/978-3-030-54367-9_5

Document status and date:

Published: 01/12/2020

DOI:

10.1007/978-3-030-54367-9_5

Document Version:

Accepted author manuscript (Peer reviewed / editorial board version)

Document license:

CC BY-NC-ND

\section{Please check the document version of this publication:}

- A submitted manuscript is the version of the article upon submission and before peer-review. There can be important differences between the submitted version and the official published version of record.

People interested in the research are advised to contact the author for the final version of the publication, or visit the DOI to the publisher's website.

- The final author version and the galley proof are versions of the publication after peer review.

- The final published version features the final layout of the paper including the volume, issue and page numbers.

Link to publication

\footnotetext{
General rights rights.

- You may freely distribute the URL identifying the publication in the public portal. please follow below link for the End User Agreement:

www.umlib.nl/taverne-license

Take down policy

If you believe that this document breaches copyright please contact us at:

repository@maastrichtuniversity.nl

providing details and we will investigate your claim.
}

Copyright and moral rights for the publications made accessible in the public portal are retained by the authors and/or other copyright owners and it is a condition of accessing publications that users recognise and abide by the legal requirements associated with these

- Users may download and print one copy of any publication from the public portal for the purpose of private study or research.

- You may not further distribute the material or use it for any profit-making activity or commercial gain

If the publication is distributed under the terms of Article $25 \mathrm{fa}$ of the Dutch Copyright Act, indicated by the "Taverne" license above, 
Radulova, E., Spendzharova, A., \& Breuer, J. (2020). The European Commission's Expert Groups: Adapting to the Contestation of Expertise. In V. Abazi, J. Adriaensen, \& T. Christiansen (Eds.), The Contestation of Expertise in the European Union Palgrave Macmillan. European Administrative Governance https://doi.org/10.1007/978-3-030-54367-9

\title{
Pre-publication version
}

\section{The European Commission's Expert Groups: Adapting to the Contestation of Expertise}

\author{
Elissaveta Radulova, Aneta Spendzharova, Johanna Breuer
}

\section{Introduction}

Policy-makers have to find feasible solutions to ever more complex and multi-faceted problems, ranging from the need to foster social integration in increasingly diverse societies to protecting critical infrastructures from cyber-attacks and regulating the use of digital currencies, to name just a few. To tackle these challenges, policy-makers seek out expert advice, which has become indispensable, considering the persisting complexity and uncertainty in the policy environment. Experts ${ }^{1}$ possess specialised knowledge and can reduce complexity by appropriately framing the problems and putting forward policy solutions, drawing on their accumulated theoretical and practical knowledge. They can help to manage uncertainly by providing detailed analysis and by applying standard routines based on previous experience (Craft and Howlett, 2013, p. 191). Experts also offer "a methodology for arbitrating between competing truth claims" (Herwig, 2014, p. 197). According to Ambrus et al. (2014), expert involvement is an important tool for increasing the legitimacy of decisionmaking. On the one hand, the inclusion of experts leads to a careful consideration of various policy alternatives and to a higher quality of the adopted decisions, thus ensuring input and output legitimacy. On the other hand, experts' involvement enhances throughput legitimacy due to the inclusiveness, transparency and the deliberative nature of the decision-making process (Ambrus et al., 2014, pp. 5-6). Owing to this effect of increased legitimacy, over time,

\footnotetext{
${ }^{1}$ According to Grundmann and Stehr (2011, p. 40) experts are "mediators between producers of knowledge and users of knowledge; and thus, between those who create the capacity to take action, and those whose task it is to act."
} 
the systematic inclusion of expert advice has become a key component of contemporary governance.

The legitimacy of expert advice has, however, come under attack in the current post-truth debate which challenges the assumption about the positive role of expertise in the policymaking process. Political actors such as Michael Gove (see Mance, 2016; White, 2016) have questioned the authoritative position of experts and countered evidence-based arguments with "alternative facts," as exemplified by Nigel Farage (Gillet, 2017) and Donald Trump (for an extensive discussion see Nichols, 2017). In essence, this indicates a strong perception among some politicians that experts are strategically used by policy-makers to justify political choices - a message which they have also expressed in election rallies and media campaigns aimed at the general public. Particularly successful in this context was Beppe Grillo in Italy who amplified the message that expert-based technocratic policy solutions are several steps removed from the concerns of 'ordinary citizens'. These rhetorical 'efforts' have led to undermining the authority of expert advice in public debates and have important implications for the general public's trust in political institutions.

Considering all of the above, it is important to investigate the main adaptation pathways undertaken in the EU political institutions in response to these challenges. In this chapter, we zoom onto a core source of expertise at the EU institutional level - the European Commission's expert groups (EGs) - and we aim to capture the trends during the period 2013-2018. Given the Commission's extensive use of and heavy dependence on expert advice the puzzle inspiring this research is to investigate empirically how the European Commission has adapted its expert group structures to the current shift toward greater contestation of expertise and expert advice in the public sphere. We selected the European Commission as the focus of our study due to its central role in the EU agenda-setting process: "in any political system, how policies are initially formulated and packaged has a strong bearing on eventual outcomes" (Princen \& Rhinard, 2006, p. 1119). Moreover, this is the institution that relies most extensively on expert input while drafting legislative and policy proposals. The five-year period was selected to capture any changes that have taken place while the complex system of EGs has experienced increased scrutiny and legitimacy critiques. We take into account the growing structural contestation in the European policy environment (see Introduction by Abazi et al., 2018). This form of contestation is raised by stakeholder groups which criticise the lack of transparency, the structural biases or the privileged position of certain expert views over others in institutionalised decision-making. Typically, the contestation lines are between 
representatives of non-governmental organisations (NGOs) and civil society groups on the one hand and business interests or industrial capital on the other hand.

This chapter is structured as follows: to begin with, section 2 outlines the state of the art, the research design of the study, the case selection and the data sources. In section 3, we examine the broad trends in the entire EG system and across all Commission DGs. Section 4 presents two case studies which allow us to investigate the concrete adaptation pathways to the contestation of expertise at the level of individual expert groups. Lastly, section 5 summarises the main findings of the chapter.

\section{State of the art and research design}

The Commission is at the heart of EU policy-making, charged with the crucial role to initiate legislation for the complex EU system of multi-level governance. Throughout the decades of European integration, the Commission has systematically resorted to external expert advice. Its permanent staff of about 33,000 civil servants ${ }^{2}$ is advised by 23,491 experts $^{3}$ divided among 770 expert groups. In other words, the Commission is a relatively small bureaucratic organisation, which has to address the "functional demands of an ever-expanding European Community for technical information and expertise" (Vos, 1999, p. 19) and, therefore, depends on input from external experts. Figure 1 displays the total number of Commission expert groups since 1985.

Figure 1: Number of Commission expert groups, 1985-2018

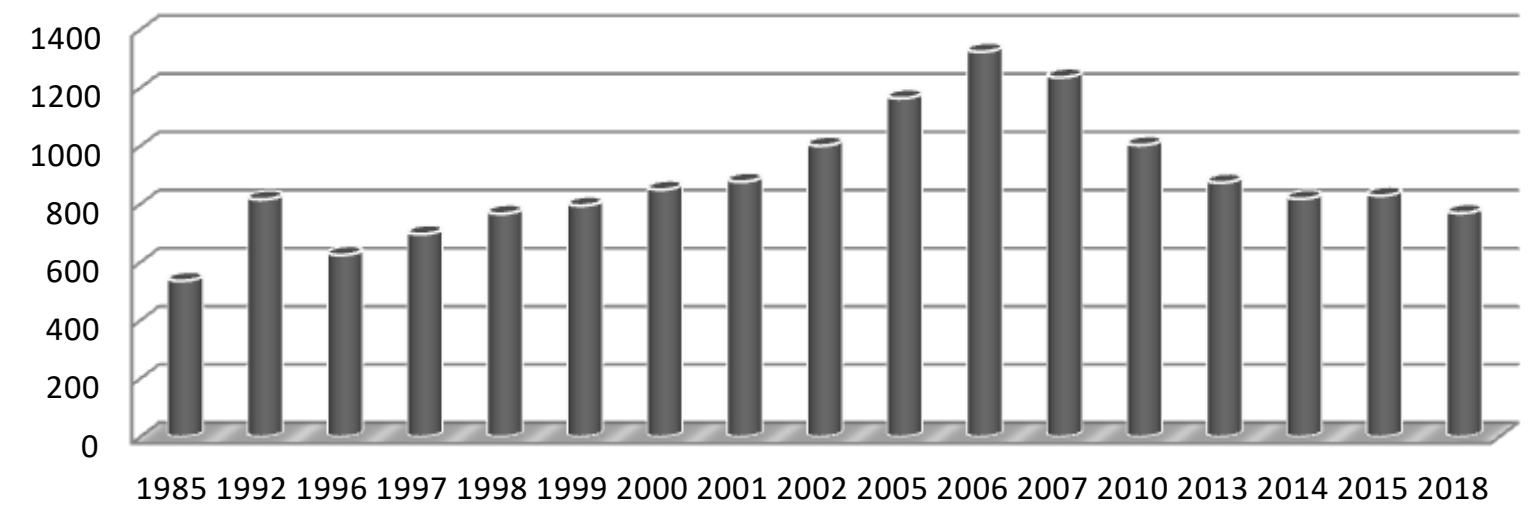

\footnotetext{
${ }^{2}$ European Commission (2018): https://europa.eu/european-union/about-eu/figures/administration_en (accessed on 10 February 2018).

${ }^{3}$ Data from the Register of European Commission Expert Groups extracted on 6 February 2018.
} 
Sources: Metz (2013); Blomeyer and Sanz (2015); Authors' own calculation based on Commission data

As highlighted by Metz (2013, p. 269), expert groups can be viewed as an important asset for the Commission to manage its complex policy environment and to acquire the resources demanded to perform its tasks. One of the core functions of the expert groups is to increase the problem-solving capacity of the Commission's decision-making. This mode of knowledge utilisation is known as instrumental (Schrefler, 2010, p. 315), meaning that scientific expertise provides specialised information that fosters a collective discussion and search for scientifically-based solutions to existing problems (see also Haas, 1992, p. 2). In this context, information is used as factual evidence to solve a policy problem (Weiss, 1979). Scholars have also identified other forms of expert knowledge utilisation. Next to instrumental, there is also a strategic use of expertise with two modalities - a substantiating and a legitimising one (Schrefler, 2010, p. 315). A substantiating function is observed when expert advice is used to promote and/or justify predetermined policy preferences and provide reasons for an already defined course of action. A legitimising function is observed when expert advice is used to lend greater credibility to the decision-making process and policy outcomes. In this context, the involvement of experts is symbolic and primarily taps into the experts' reputation for reliable scientific advice, rather than into their substantive knowledge and careful analysis. Based on Schrefler's analysis (2010, p. 321), under conditions of high contestation, such as in the current period of post-truth politics, we expect to find less instrumental and a more strategic use of expertise.

Similarly to Schrefler's (2010) approach, Metz (2013, p. 270) views the expert groups as an important arena for the articulation of policy opinions of a variety of relevant stakeholders. She highlights three different uses of expertise in the policy process: a problemsolving use, a substantiating one and a consensus-building one. Firstly, the problem-solving use is rather technocratic and refers to drawing on experts' factual and practical knowledge and insights when drafting legislation (Metz, 2013, p. 271). Secondly, in the substantiating mode, the Commission uses the information provided more strategically to substantiate its positions and justify a preferred course of action. Thirdly, in the consensus-building mode, the Commission values experts and their knowledge, but it primarily seeks to bring together diverse viewpoints in a more formal institutional setting and identify possible agreements that can serve as the basis for widely accepted legislation (Metz, 2013, p. 272). In the third mode, 
the expert groups' institutional context facilitates negotiations based on open communication and trust, thus, helping to accommodate diverging interests.

Existing studies have reached different conclusions about the observed mix of the instrumental and strategic use of expert knowledge by the Commission. Rimkute and Haverland (2015) find that the strategic use of knowledge, albeit present, is not highly prominent in the process of legislative proposal drafting. On the contrary, they report that the instrumental use is perceived as dominant by the scientific contributors to deliberations. By contrast, other scholars (Hartlapp, 2015; Radulova and Mkheidze, 2015) have found increasing politicisation of the Commission and, consequently, a more strategic political use of external experts.

Against this backdrop, the aim of our contribution is to provide a theoretically-informed exploratory study of how the Commission has adapted its expert group structures to the contestation of expertise against the backdrop of the post-truth debates. Particularly, we focus on one commonly advanced claim when contesting expert advice, namely, that expert groups are prone to "corporate capture" by powerful industry groups. If this claim is valid, the composition of the expert groups would show a dominance of corporate or business interests vis-à-vis smaller companies, public actors, NGOs or academic experts. We probe the claim at two levels of analysis: first, in section 3 we survey macro level changes and, second, in section 4 we investigate in-depth the micro level dynamics in two specific expert groups. This set-up allows us to examine systematically the adaptation pathways of the Commission's expert groups system to the greater contestation of expertise.

To conduct the analysis, section 3 examines the system of expert groups as a whole, based on primary Commission documents, quantitative data extracted ${ }^{4}$ from the Register of the Commission's expert groups, interviews and the existing academic literature. We draw on statistical data about the number and composition of the expert groups found in: Larsson (2003), Larsson and Murk (2007), Gornitzka and Sverdrup (2008, 2011) and Metz (2013, 2015). The most recent and comprehensive study on this topic was commissioned by the European Parliament and executed by Blomeyer and Sanz (2015), which we supplemented with the most recent data from 2018.

\footnotetext{
${ }^{4}$ The Register data are from the 6 February 2018 and were provided by the General Secretariat of the Commission Unit B2.
} 
After the survey of macro level changes in section 3, section 4 focuses on the micro level dynamics in two expert groups. The case selection is based on high societal interest and media attention. Moreover, the selected expert groups advise on important sectors of the economy, which deal with highly specialised and complex issues and generate a high level of structural contestation. Given the high contestation and the large degree of public scrutiny, these can be considered most likely cases to find systematic adaptation in the work of the expert groups. The concrete EGs were selected from the Register of Commission Expert Groups applying the search criteria for an active expert group and containing type $\mathrm{C}$ experts (the category encompassing corporate actors). The following two expert groups were selected for further examination after excluding ad-hoc and informal or too narrowly technical EGs:

- $\boldsymbol{E 0 3 4 8 5}$ - High-Level Expert Group on Sustainable Finance

- E02611 - Expert Group on the exchange of information on Best Available Techniques related to industrial emissions (IED Article 13 Forum)

Next to high issue salience and contestation, the two case studies represent Commission Directorate-Generals (DGs) which are quite active in the EU legislative process: DG FISMA and DG ENV (see Figure 2). In DG FISMA we observe a pronounced reduction in the consulted expert groups from 26 in 2013 to 17 in 2018. While in the past DG ENV was one of the most active DGs to consult expert groups, during the studied period the number of EGs for this DG has oscillated between 50 and 60 .

Figure 2: Number of expert groups consulted by DG ENV and DG FISMA, 2013-2018

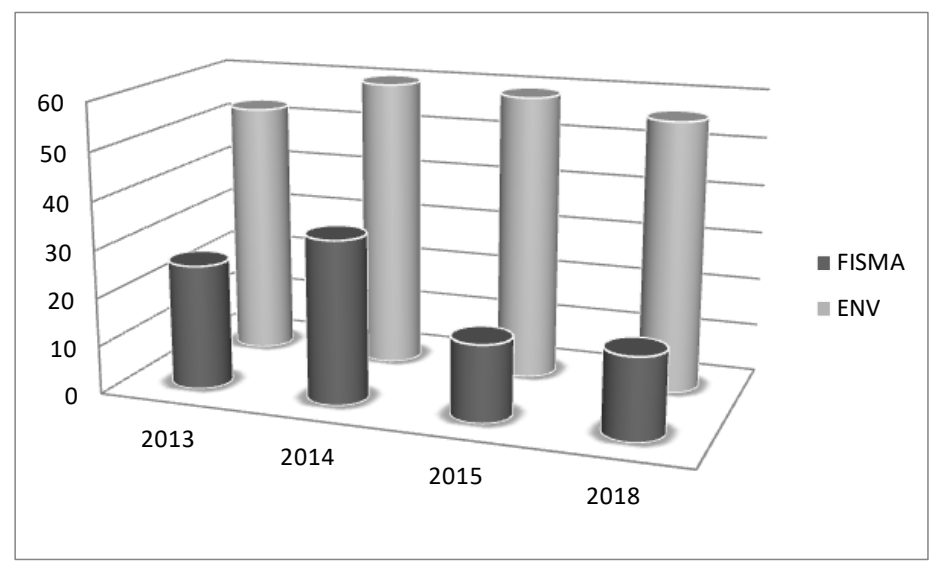

Sources: Authors' calculation based on Blomeyer and Sanz (2015) and Commission data (2018) 


\section{The (changing) landscape of the European Commission expert groups}

The Commission expert groups play an important advisory role in the agenda-setting and policy formulation stages of the policy process when the Commission drafts legislative and policy proposals. ${ }^{5}$ This section examines the changes in the pre-legislative advisory structures of the Commission in response to the challenges of the post-truth period. In sub-section 3.1. we summarise the efforts to ensure greater transparency, such as the establishment and subsequent reforms of the Commission's Register of Expert Groups. The most notable reform in this context was the adoption of new Horizontal Rules on the creation and operation of Commission Expert Group in 2016 and establishing an obligatory link between the Transparency Register and the Register of Expert Groups. Secondly, in sub-section 3.2. we trace the efforts to achieve a more balanced composition between representatives of industrial/corporate and civil society/non-governmental interests. The key evidence in this respect is the recruitment of experts via public calls as well as the new obligatory link between the Transparency Register and the Register of Expert Groups. These measures are intended to reduce the likelihood of "corporate capture" of the expert groups.

\subsection{The Commission's Register of Expert Groups as an instrument of transparency and accountability in EU expert governance}

Blom (this volume) discerns two waves in the scholarship of EU committees - the first wave focused on comitology committees, while the second one examines the expert groups. Scholarly attention to the Commission's pre-legislative advisory structures is relatively new (Larsson, 2003, p. 127) and it has been particularly challenging to obtain reliable data about the active expert groups and their composition. The launch of the Commission's Register of Expert Groups in 2005 considerably improved the access to this data (Larsson and Murk, 2007, p. 66) and, hence, it also enhanced the transparency of advice provision. In fact, it has made new research possible, allowing more systematic and also more critical studies (Gornitzka and Sverdrup, 2008, p. 726). The Register currently offers information about the active and "on hold" expert groups, their members, mandate, topics of discussion and the respective lead DG (European Commission, 2016b, pp. 15-17). All in all, the 2016 reform of

\footnotetext{
${ }^{5}$ Van Balleart (2015) estimated that expert groups assisted the Commmission in preparing about a third of the legislative proposals, especially in dossiers of more transversal nature and/or when the legislative proposal concerned standard-setting.
} 
the Register, accomplished through the adoption of the new Horizontal Rules on the creation and operation of Commission Expert Groups aimed at a high level of transparency.

While the statutory transparency provisions are adequate, their application varies substantially between the Commission's different DGs. Under the current Horizontal Rules, the DGs are expected to "ensure publication of the agenda and other relevant background documents in due time ahead of the meeting, followed by the timely publication of the minutes" (Ibid., Article 26). However, there is a big variation in how different DGs implement the provisions. During our own work with the Register, we found that regular updates of the documents and information about a group's activity were often lacking and sometimes already uploaded documents were eventually removed.

In sum, the launching and continuous improvement of the Register via the different releases has brought the pre-legislative expert groups into the spotlight and, therefore, it has considerably improved access to data. However, the sheer existence of data is not enough - it should also be easily extractable and comparable over time in order to enable systematic comparisons and analysis of the trends over time. At present, the General Secretariat is considering how to provide to all interested parties standardised reports with structured data in regular time intervals (Interview no. 2).

There are also challenges with the reliability of data (see Blomeyer and Sanz, 2015, p. 30 on organisation name entries). Data reliability is safeguarded by the formal rules of the Register. In practice, however, there are duplications and divergence in reporting the group membership due to the lack of formal cross-checking among the different DGs convening the expert group (Interview no. 2). Taking measures to ensure that the Commission's Secretariat General has the mandate and resources to achieve data accuracy and reliability is still a very important priority. Otherwise, the advantages of better information provision cannot be fully converted into a better understanding of who actually participates in the expert groups.

\subsection{A better balance in the representation of corporate and civil society interests?}

In this sub-section we take stock of the measures undertaken by the Commission to address the frequent critiques regarding the composition and operation of its expert groups. Civil society organisations (ALTER-EU, 2008, 2013, 2016), the European Parliament (see Blomeyer and Sanz, 2015) and the European Ombudsman $(2014,2016)$ have systematically 
raised concerns about major deficiencies in the advisory structures of the EU executive, such as an inconsistent categorisation of expert group members, an overrepresentation of corporate interests and, notably, frequent instances of conflict of interest for individual experts appointed in their personal capacity (the so-called type A experts in Table 1). The instances of conflict of interest are a key concern for NGO stakeholders, observers and academics alike, because they show that representatives of business interests can assume the position of "experts," while in practice these actors engage in policy advocacy. Such practices may eventually lead to corporate dominance and may skew legislation toward the preferences of the most well-organised business interests. The strategic use of the "corporate capture" message in the media and in election rallies has contributed to the gradual erosion of the general public's trust in expert judgment and policy proposals. 
Table 1: Categorisation of experts for the purposes of the Register of Commission Expert Groups

\begin{tabular}{|c|c|}
\hline Type A & $\begin{array}{l}\text { Individuals appointed in a personal capacity, acting independently and } \\
\text { expressing their own personal views. }\end{array}$ \\
\hline Type B & $\begin{array}{l}\text { Individuals appointed to represent a common interest shared by stakeholder } \\
\text { organisations in a particular policy area. They do not represent individual } \\
\text { stakeholders, but a particular orientation common to different stakeholder } \\
\text { organisations. They may be proposed by stakeholder organisations. }\end{array}$ \\
\hline Type C & $\begin{array}{l}\text { Organisations in the broad sense of the word including companies, } \\
\text { associations, NGOs, trade unions, universities, research institutes, law firms } \\
\text { and consultancies. }\end{array}$ \\
\hline Type D & Member States' authorities - national, regional or local. \\
\hline Type E & $\begin{array}{l}\text { Other public entities, such as authorities from non-EU countries (including } \\
\text { candidate countries), EU bodies, offices or agencies, and international } \\
\text { organisations. }\end{array}$ \\
\hline
\end{tabular}

Source: European Commission (2016a)

The Brussels-based Alliance for Lobbying Transparency and Ethics Regulation, commonly known as ALTER-EU, has been particularly concerned about instances of corporate capture in EU policy-making and has collected evidence of such activities. According to their assessment, "big business interests, meaning corporate lobbyists dominate EGs" (ALTER-EU, 2013, p. 3). For example, they estimated that in 2013 almost $80 \%$ of the new appointments to the EGs of the DG Taxation and Customs Union represented corporate interests (ALTER-EU, 2013, p. 3). Similarly, Chalmers (2014, p. 976) has found that being a member in an expert group depends on "superior resources, EU-level interests and existing institutionalised ties to decision-makers." In 2018, ALTER-EU still continues to encounter business and industry-dominated EGs (Interview no. 3).

The potential problem with type A experts outlined above is not unique. The other expert categories are also open to corporate overrepresentation and, hence, to potential bias in the issued expert advice. While it is challenging to produce an exact estimate of the degree of domestic corporate capture in the EU member states, it cannot be ruled out that the 
representatives of the member states (type D) and of other public authorities (type E) could be advocating for particular business interest despite the signed conflict of interest declaration (Interview no. 3). Such model of influence would additionally amplify business/industry preferences during the expert deliberations. While the avenues of advocacy of private interests via the type $\mathrm{A}$ or type $\mathrm{D} / \mathrm{E}$ categories is rather indirect, type $\mathrm{B}$ and $\mathrm{C}$ experts are overt and direct channels for representation of special interests in Commission EGs. This is why our analysis now turns to examining the composition of experts per type and DG.

Table 2: Number of experts per type and per Commission DG

\begin{tabular}{|c|c|c|c|c|c|c|}
\hline DG & Type A & Type B & Type C & Type D & Type E & Total \\
\hline AGRI & 62 & & 461 & 308 & & 831 \\
\hline BUDG & 5 & & & 56 & & 61 \\
\hline CLIMA & & & 42 & 112 & 10 & 164 \\
\hline CNECT & 63 & 1 & 109 & 527 & 10 & 710 \\
\hline COMP & & & & 28 & & 28 \\
\hline DEVCO & & & 56 & 364 & 1 & 421 \\
\hline DGT & 10 & & & & & 10 \\
\hline EAC & 21 & & 63 & 460 & 101 & 645 \\
\hline ECFIN & & & 16 & 159 & 7 & 182 \\
\hline ECHO & & & & 192 & 28 & 220 \\
\hline EMPL & 21 & 191 & 276 & 879 & 119 & 1486 \\
\hline ENER & 4 & & 64 & 557 & 10 & 635 \\
\hline ENV & 23 & & 299 & 1501 & 100 & 1923 \\
\hline EPSO & & & & 28 & & 28 \\
\hline ESTAT & 6 & & 1 & 2229 & 97 & 2333 \\
\hline FISMA & 18 & 48 & 125 & 263 & 12 & 466 \\
\hline FPI & & & & 28 & & 28 \\
\hline GROW & 49 & 26 & 777 & 2279 & 191 & 3322 \\
\hline HOME & 31 & & 58 & 751 & 67 & 907 \\
\hline HR & & & & 55 & & 55 \\
\hline JRC & 12 & & 1 & 27 & & 40 \\
\hline JUST & 129 & 67 & 87 & 780 & 47 & 1110 \\
\hline MARE & 32 & 4 & 58 & 205 & 11 & 310 \\
\hline MOVE & 17 & 2 & 567 & 1031 & 100 & 1717 \\
\hline OLAF & & & & 112 & 3 & 115 \\
\hline REGIO & 30 & & 60 & 196 & 15 & 301 \\
\hline RTD & 625 & 65 & 99 & 201 & 59 & 1049 \\
\hline SANTE & 119 & & 277 & 1360 & 93 & 1849 \\
\hline $\mathrm{SG}$ & 5 & 18 & 22 & 112 & 4 & 161 \\
\hline TAXUD & 14 & & 217 & 1805 & 66 & 2102 \\
\hline TRADE & & 30 & 28 & 224 & & 282 \\
\hline Grand Total & 1296 & 452 & 3763 & 16829 & 1151 & 23491 \\
\hline
\end{tabular}


Source: European Commission, Register of EGs, 6 February 2018

Table 2 shows considerable variation in the composition of the expert groups, and respectively in the proportion of the five types of experts, across DGs and policy sectors. Moreover, the variation is even greater at the level of the individual experts: within the type B and type $\mathrm{C}$ experts, there are further categories to be explored, such as trade/business association, company, NGO, academia or research institute. Critical observers, such as ALTER-EU or the Ombudsman, suspect that "corporate capture" is facilitated precisely by the (dis)balance at this sub-category level. For these reasons, in November 2011, the European Parliament put a reserve on the Expert Group Budget and posed to the Commission four conditions under which the reserve would be lifted (Blomeyer and Sanz, 2015, p. 16). Additionally, the Ombudsman, Emily O'Reilly, insisted in 2014 and again in 2016 on several measures with regard to the Commission's EGs (European Ombudsman, 2014, p. 5). Among the demands is the achievement of a balanced composition of the expert groups, linking the Register of EGs with the Transparency Register and releasing regular public calls for applications.

In principle, the Commission DGs have full discretion regarding whether to convene an EG and who will participate in it. Unlike the Commission's comitology committees, which have a stronger legal basis, the pre-legislative EGs do not have to follow a strictly prescribed process of group selection. Still, some adjustments have taken place despite the DGs' relatively high discretion in the convening and management of the EGs. Particularly, the Juncker Commission (in office since 2014) declared transparency and accountability to be a high priority and, therefore, it has undertaken a number of measures to achieve these objectives. For example, it releases a public call for applications for every expert group, with a four-week minimum ${ }^{6}$ deadline for all calls. Furthermore, type B and C experts are now obliged to also register themselves in the EU's Transparency Register. Lastly, the Commission has put in place new and more systematic checks of potential conflict of interest for individual experts appointed in their personal capacity to make sure that type A experts do not represent industrial/private sector interest under the guise of "serving in a personal capacity."

These measures have been recommended by the European Ombudsman (2014, p. 5) and have gradually taken concrete shape through the revised Horizontal Rules (2016), the

\footnotetext{
${ }^{6}$ Exceptions are made in case of emergency and also for the member state authorities which can appoint their own EG representatives.
} 
consecutive new releases of the Register and by establishing a link between the Register of EGs and the Transparency Register (2017). The changes fit well with the renewed emphasis that the Juncker administration has placed on the ethical aspects of EU governance, such as the publication of meeting agendas of the Commissioners, their cabinet members, and of the Directors-General as well as the requirement that Commissioners do not to meet with organisations (or self-employed individuals) which are not registered in the Transparency Register. Another step toward greater transparency is the Commission's commitment to come forward with a proposal for a mandatory Transparency Register (Interview no. 1). Furthermore, the revised Horizontal Rules oblige each expert group (or rather its designated administrative support from the DG) to timely provide the agenda and the relevant other documents on the respective EGs webpage. This can be considered as adjustment in line with the requests for greater accountability and transparency in the functioning of the EGs (Interview no. 2).

Have the changes outlined above led to a better balance in the expert groups? Next we evaluate the effects of the recent changes on the composition of the expert groups to supplement recent findings (Gornitzka and Sverdrup, 2011; Metz, 2015; Blomeyer and Sanz, 2015) with new evidence about variation in the consulted types of experts.

Figure 3: Percentage change in types of experts in the Commission Expert Groups, 20142018

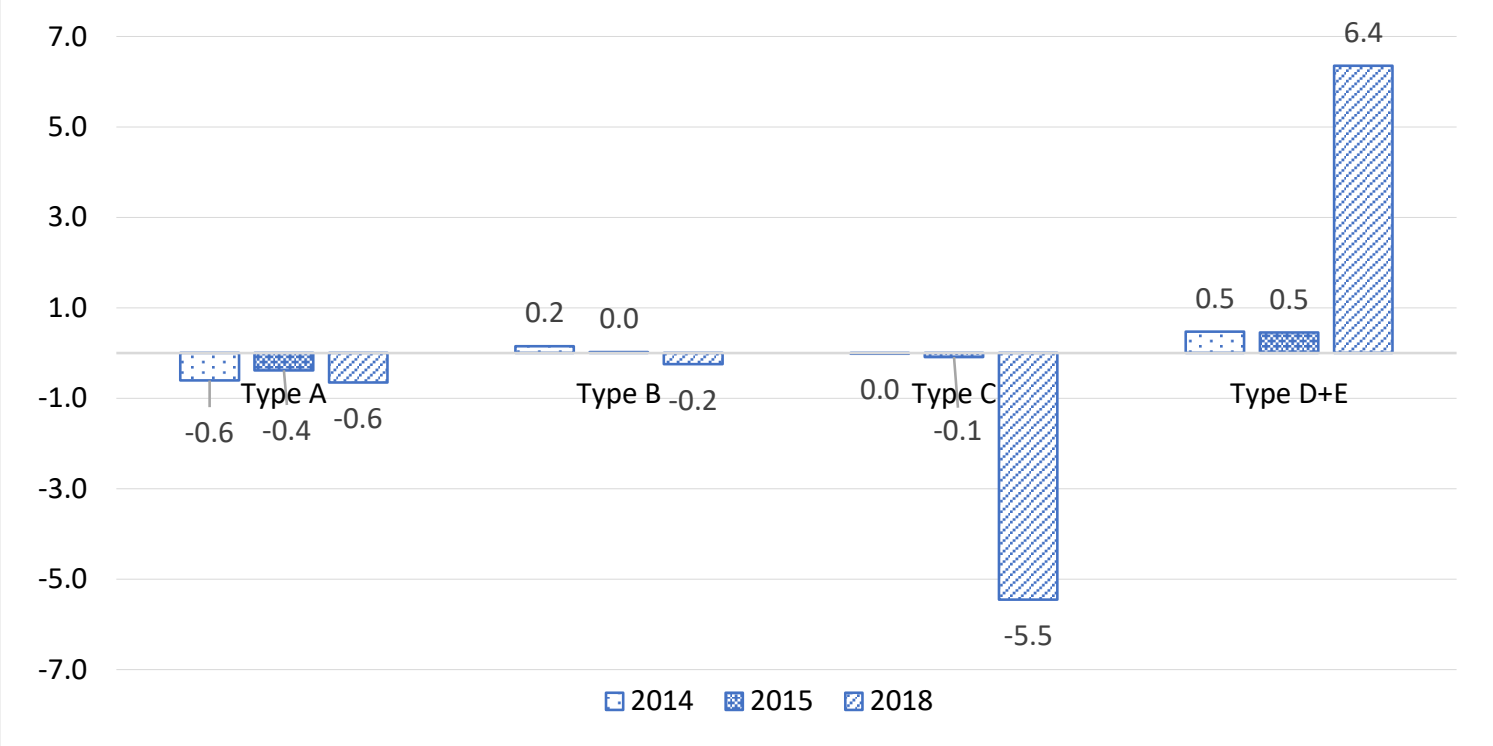

Source: European Commission data, Register of EGs (2018) 
Figure 4: The balance between different types of exerts in the Commission Expert Groups, 2014-2018

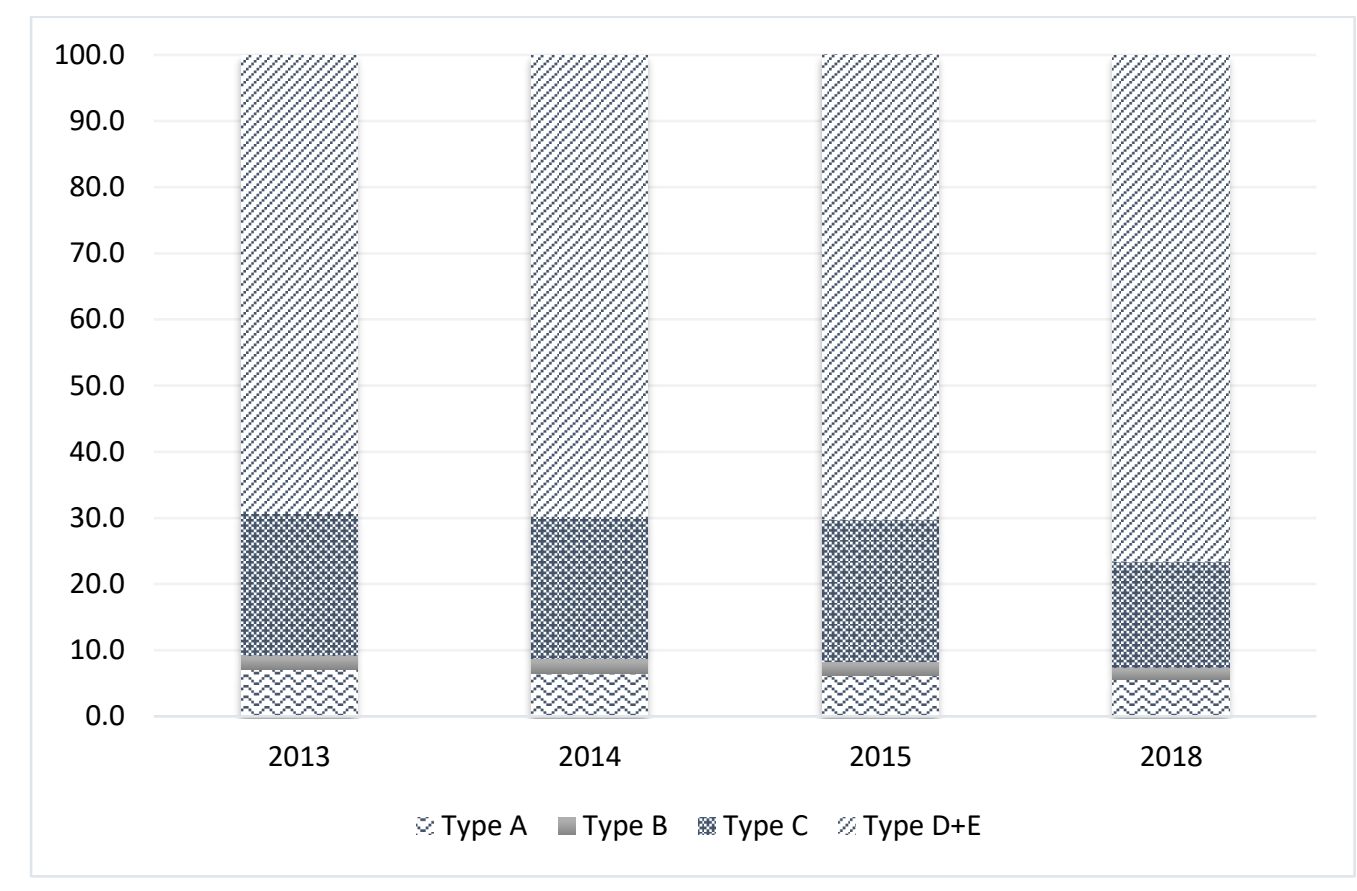

Source: European Commission data, Register of EGs (2018)

Figures 3 and 4 suggest that the demands to re-label type A experts have been largely addressed, as shown by the decreased number of consulted type A experts in the period 20132018. There is an indication that the number of consulted type $\mathrm{C}$ experts also decreased in 2018 compared to 2015 . To explore these insights more in-depth, we need the breakdown per subcategory of experts and policy sector, which is not available from the Register of EGs but from the EU's Transparency Register. ${ }^{7}$ This register contains data in six categories, depending on the type of represented interest:

I. Professional consultancies/law firms/self-employed consultants

II. In-house lobbyists and trade/business/professional associations

III. Non-governmental organisations

IV. Think tanks, research and academic institutions

V. Organisations representing churches and religious communities

VI. Organisations representing local, regional and municipal authorities, other public or mixed entities

\footnotetext{
${ }^{7}$ The requirement that all type B and C experts should be registered in the Transparency Register allows crosschecking between the two registers and collecting more detailed data per sub-category.
} 
According to the Transparency Register classification, the type I and II categories stand for business and corporate interests, while types III, IV, V and VI indicate public and NGO interest representation. Focusing on the policy sectors of the two case studies in section 4, Finance and Environment, we cluster the data in two categories to gauge the balance between private business interests, on the one hand, and public and NGO interests on the other hand. The results presented in Table 3 below indicate a two to one prevalence of private business interests over public and NGO ones.

Table 3: Distribution of interest representation per category of the Transparency Register for the sectors of Environment and Finance (March 2018)

\begin{tabular}{|c|c|c|}
\hline & Types I and II & Types III, IV, V and VI \\
\hline Finance & $41(66 \%)$ & $21(34 \%)$ \\
\hline Environment & $188(63 \%)$ & $110(37 \%)$ \\
\hline $\begin{array}{c}\text { All policy domains } \\
\text { (entire Transparency } \\
\text { Register) }\end{array}$ & $7085(60 \%)$ & $4600(40 \%)$ \\
\hline
\end{tabular}

Source: European Commission data, Transparency Register (2018)

While the general distribution of interest representation in the two analysed sectors showed that business interests have a more substantial representation, it is unclear what the implications of this trend may be for the composition of expert groups and the deliberations and decision-making in individual EGs. Therefore, the next two sections focus on unpacking expert group advice in two particular cases.

\section{Adaptation pathways at the level of individual expert groups}

After reviewing the macro level adaptations, we now turn to concrete adjustment pathways at the micro level. We examine two highly salient policy areas where recent legislative changes have been introduced. The key questions are how the Commission manages the heterogeneity of actors and views, in particular among type $\mathrm{C}$ experts, and how it copes with the growing structural contestation of expert advice. In addition, we assess the relationship between the Commission and its expert groups using Metz' (2013, 2015) typology of: (1) problemsolving, (2) substantiating and (3) consensus-building use of expertise.

\subsection{Case study of the High-Level Expert Group on Sustainable Finance}


Firstly, we investigate the High-Level Expert Group (HLEG) on Sustainable Finance (Expert Group E03485). This advisory expert group was created with a Commission decision and tasked with presenting "policy recommendations that: (a) sets out the scale and dimensions of the challenges and opportunities that sustainable finance presents; and (b) recommends a comprehensive programme of reforms to the EU financial policy framework, including a clear prioritisation and sequencing" (European Commission, 2016d, p. 3). The group had a year to submit a final report, including carrying out a stakeholder questionnaire and preparing an interim report. The case analysis draws on the HLEG's reports, the minutes for each meeting obtained from the Register of the Commission's Expert Groups as well as additional press releases and Commission documents.

The HLEG consisted of 20 members and nine observers. Seven of the members were from the UK, four - from France, two - from the Netherlands, two - from Germany and one from Sweden, Italy, Finland, Luxembourg and Poland, respectively. These are type B members: "individual expert appointed as a representative of a common interest" (Register, "Expert Group explained"). In terms of professional affiliation, the 20 members broadly belong to three groups: i) one academic, ii) three members from non-banks or non-profit organisations with a strong research interest in sustainability and iii) fourteen members from banks, funds or other private entities. The third group is the most numerous one and includes primarily banks and funds which see sustainability and the protection of the environment as a fundamental part of their business model, such as APG Group, Mirova, Climate Bonds, Eurosif, Novethic, Trucost, $2^{\circ}$ initiative. Other members in the third group represent the more general banking sector landscape, such as ALECTA, the Polish Bank Association, Deka, Finance Finland, AMC Strategy, London Stock Exchange, Luxembourg Stock Exchange and Aviva. The HLEG members did not include individuals working in a personal capacity or representatives of the member states' authorities.

The observer members of the HLEG could take part in all meetings and can be categorised as type $\mathrm{C}$ and type $\mathrm{E}$ experts. It is evident from meeting documents that the observers also participated actively in the discussions, which is in line with point 8 of the Rules of Procedure (Register, "HLEG", Agenda $11^{\text {th }}-12^{\text {th }}$ September 2017). The type C expert observers were the European Association of Long-Term Investors, the International Capital Market Association and the Nordic-Investment Bank. Participating type E observers were European agencies and international institutions, such as the European Environment Agency, the European Investment Bank, the European Systemic Risk Board, the Single Resolution 
Board, the United Nations Environment Programme and the United Nations Principles for Responsible Investment. In sum, the financial industry was well-represented in the composition of the HLEG group. In addition, type $\mathrm{C}$ and $\mathrm{E}$ observers came from more heterogeneous international backgrounds.

The Commission' selection procedure for the HLEG defined that the group's composition should ensure "a geographical and a gender balance, as well as a balanced representation of relevant know how and areas of interest" (European Commission, 2016c, p. 7). However, more than half of the members were from the UK and France, which suggests an overrepresentation of member states with large banking sectors. In terms of gender balance, there were seven female and thirteen male experts. The prevalence of male experts and the male leadership of the HLEG is somewhat surprising, considering that sustainable finance generally exhibits more gender equality (Robinson-Tillett, 2017).

The HLEG included experts from banks and funds which are interested in sustainability issues. However, the group did not include stakeholders that hold more "exceptional" views about sustainability in finance. Jeucken and Bouma (2001, p. 34) explain that in sustainable banking, the "bank does not look for the highest financial rate of return, but for the highest sustainable rate of return, while being profitable in the long run." Organisations advocating this view and more radical policy change, such as introducing capital requirements with sustainability weightings, are the Global Alliance for Banking on Values (GABV), Finance Watch and Mission 2020. Due to the exclusion of these more "extreme" actors and the resulting more mainstream industry composition, the expert group reflected more "mainstream" business interests. In turn, this led to less contestation in the group deliberations and outcomes.

The HLEG's mandate was quite broad. The Commission (2016d, p. 3) requested a "set of policy recommendations [...] [with] a comprehensive programme of reforms to the EU financial policy framework". Content-wise, the aim was to achieve increased investment in sustainable investment projects as well as to ensure that financial institutions and supervisors "protect the stability of the financial system from risks related to the environment" (Commission 2016d, p. 3). Lastly, the Commission was interested in policies applicable to the entire EU in the context of the single market and, especially, geared toward consolidating the EU's leadership in sustainable finance. 
The HLEG's broad scope is also reflected in the group's initial search for an appropriate definition of "sustainable finance". A clear definition sets boundaries to what will be included or excluded in the discussions. With the first meeting the DG FISMA introduced "relevant issues/challenges to enhancing sustainable finance such as definitions and analytical tools/ processes" (Register, HLEG, Minutes 25 th January 2017, p. 2). Subsequently, multiple definitions of "sustainable finance" were given in the interim report but they still remained rather broad, such as "[f]inance fostering sustainable economic, social and environmental development" (HLEG, 2017a, p. 12).

A distinctive feature of the HLEG's deliberations is that there is no evidence of a high level of contestation within the group during the discussions. In the group's second meeting, the participants agreed on "[i]ntegrating sustainability into the functioning of the EU Financial System" (Register, E03485, Minutes $6^{\text {th }}$ March 2017, p.2). This would be achieved through three sets of actions: first, the adoption of different procedures in the "investment and lending chain", second, reducing "long-term and sustainability risks" and, third, answering to "structural obstacles and time misalignments" (ibid.). The early HLEG recommendations in the interim report further elaborated on these three sets of actions. Table 4 below summarises the interim and final list of recommendations, including the extent of change observed. The HLEG's final report, published in January 2018, contained five key recommendations, effectively omitting some of the more controversial recommendations formulated in the interim report. One possible explanation for the shorter list in the final report is feasibility, given the group's mandate: “The group will need to prioritise those areas where the highest leverage impact can be, particularly since urgent change is needed" (Register, HLEG, Minutes $24^{\text {th }}$ January 2017, p. 2). The final list of recommendations is geared toward more harmonisation in sustainable financial products and working methods across the EU and matches the indicated priorities well.

In sum, considering the high contestation of financial sector legislation since 2008, we expected to find more strategic use of expertise (Schrefler, 2010) in the case of the HLEG, which was indeed the case. The relatively homogenous composition of the expert group enabled the chair to steer the deliberations and, subsequently, the policy recommendations toward more moderate and pragmatic goals. Revisiting Metz' (2013) typology of the uses of expertise, this is in line with a substantiating use in order to further strengthen and harmonise the internal market in financial services as well as a consensus-building use in order to 
identify broad areas of agreement on key priorities shared among the different HLEG members.

Table 4: Interim and final recommendations of the HLEG on Sustainable Finance

\begin{tabular}{|c|c|c|c|}
\hline & $\begin{array}{l}\text { Recommendations in the } \\
\text { Interim Report (2017a) }\end{array}$ & $\begin{array}{l}\text { Extent of } \\
\text { change }\end{array}$ & $\begin{array}{l}\text { Recommendations in the Final } \\
\text { Report (January 2018) }\end{array}$ \\
\hline 1 & $\begin{array}{l}\text { "A classification system for } \\
\text { sustainable assets" (p. 55) }\end{array}$ & No change & $\begin{array}{l}\text { "Establish and maintain a common } \\
\text { sustainability taxonomy at the EU } \\
\text { level" (p. 15) }\end{array}$ \\
\hline 2 & $\begin{array}{l}\text { "A European standard and label } \\
\text { for green bonds and other } \\
\text { sustainable assets, as well as } \\
\text { labels for sustainable funds" (p. } \\
\text { 56) }\end{array}$ & No change & $\begin{array}{l}\text { "Develop and implement official } \\
\text { European sustainability standards } \\
\text { and labels, starting with green } \\
\text { bonds" (p. 30) } \\
\text { "Key elements of a retail strategy } \\
\text { on sustainable finance: investment } \\
\text { advice, ecolabel and SRI minimum } \\
\text { standards" (p. 27) }\end{array}$ \\
\hline 3 & $\begin{array}{l}\text { "Fiduciary duty that encompasses } \\
\text { sustainability" (p. 57) }\end{array}$ & $\begin{array}{l}\text { Rephrased } \\
\text { and } \\
\text { weakened }\end{array}$ & $\begin{array}{l}\text { "Clarify investor duties to better } \\
\text { embrace long-term horizon and } \\
\text { sustainability preferences" (p. 20) }\end{array}$ \\
\hline 4 & $\begin{array}{l}\text { "Disclosures for sustainability" } \\
\text { (p. 57) }\end{array}$ & & $\begin{array}{l}\text { "Upgrade disclosure rules to make } \\
\text { sustainability risks fully } \\
\text { transparent, starting with climate } \\
\text { change" (p. 23) }\end{array}$ \\
\hline 5 & $\begin{array}{l}\text { "A sustainability test in financial } \\
\text { legislation" (p. 58) }\end{array}$ & Deleted & - \\
\hline 6 & $\begin{array}{l}\text { "Create 'Sustainable } \\
\text { Infrastructure Europe"” (p. 58) }\end{array}$ & No change & $\begin{array}{l}\text { "Establish 'Sustainable } \\
\text { Infrastructure Europe"” (p. 34) }\end{array}$ \\
\hline 7 & $\begin{array}{l}\text { "Position the European } \\
\text { supervisory agencies on } \\
\text { sustainability" (p. 59) }\end{array}$ & Deleted & - \\
\hline 8 & $\begin{array}{l}\text { "Accounting standards for energy } \\
\text { efficiency" (p. 59) }\end{array}$ & $\begin{array}{l}\text { Deleted and } \\
\text { allocated to } \\
\text { "other } \\
\text { actions" }\end{array}$ & $\begin{array}{l}\text { "Accelerate action to finance } \\
\text { energy efficiency investments" (p. } \\
59)\end{array}$ \\
\hline 9 & & & $\begin{array}{l}\text { "Governance and Leadership" (p. } \\
38 \text { ) }\end{array}$ \\
\hline 10 & & & $\begin{array}{l}\text { "Include sustainability in the } \\
\text { supervisory mandate of the ESAs } \\
\text { and extend the horizon of risk } \\
\text { monitoring" (p. 41) }\end{array}$ \\
\hline
\end{tabular}




\subsection{Case study of the Industrial Emissions Directive Article 13 Forum}

The expert group E02611 is formally called "Expert Group on the exchange of information on Best Available Techniques related to industrial emissions" but it is commonly known as "IED Article 13 Forum." The group was established in 2011, in compliance with Article 13 of the Industrial Emissions Directive (IED) - 2010/75/EU Recast. It is the successor to the Information Exchange Forum, created under the previous Integrated Pollution Prevention and Control Directive 2008/1/EC. Both Directives define the framework for issuing environmental permits to large industrial installations (refineries, iron and steel plants, etc.) on the territory of the European Union, and aim to control and reduce pollution from these largest industrial sources.

The regulatory approach pursued in the IED is co-regulatory - the regulated parties actively participate in the process of standard-setting which has to be complied with - through the provision of data about levels of industrial emissions released in the environment (air, water and soil). This mode of steering brings many advantages: it is more inclusive, ensures active stakeholder participation and a more deliberative nature of the governance process. Furthermore, it brings about lower transaction costs of negotiating an agreement between heterogeneous actors, higher levels of compliance and lower costs of the regulatory process itself (Koutalakis et al., 2010, pp. 330-331; Best, 2003). The IED previews (Article 13) an information exchange about the levels of industrial emissions between member states, the industries concerned, non-governmental organisations promoting environmental protection and the Commission. This exchange takes place via the IED Article 13 Forum, which was created as a formal expert group through Commission decision (2011/C 146/03) of 16 May 2011, whereby the lead DG is Environment and the Joint Research Centre (JRC) is the associated DG. The main function of the Forum is to assure the largest possible consensus regarding the BAT reference documents described below (known as BREF). The BREFs are drafted in a complex procedure known as the Sevilla process led by the European Integrated Pollution Prevention and Control Bureau (EIPPCB), which is part of the Joint Research Centre. The Forum plays a coordinative role and steers the general and horizontal aspects of the information exchange (Schoenberger, 2009, p. 1527). Furthermore, the Technical Working Groups (TWGs) are made up technical experts representing the member states, industry or NGOs and play an important role in drawing up and reviewing the BREFs. 
There are more than 50,000 large industrial installations in the EU which must operate according to the EU standards for prevention and control of pollution, and therefore obtain an environmental permit that certifies that. The permit confirms compliance with binding emission limits (e.g. for sulphur dioxide) based on a set of Best Available Techniques (BATs) endorsed for the Union as a whole. The primary function of the expert group IED Article 13 Forum is to draw up, review and update BAT reference documents (BREFs). The BREFs are complex technical manuals of hundreds of pages which set out norms and good practices in the management of industrial emissions. Once drafted with the largest possible consensus (Article 13 IED) and adopted - by a Comitology committee (Article 75 IED) - the BREFs are used by the member state authorities as the reference standard for setting permit conditions to large industrial installations. Clearly, the content of a BREF and especially the emission reference standards it endorses have far-reaching (material) consequences for the EU member states and their regulated industries. Therefore, the process of BREF endorsement is highly political.

The main data sources used in the case study in order to reconstruct this contestation and the coping strategies on the side of the Commission are the available constitutive documents (e.g. the founding Commission decision, the Rules of Procedure) and the minutes of the IED Article 13 Forum available from the Register of Expert Groups. Moreover, an interview was conducted in the Unit C4 (Industrial Emissions) of DG Environment.

In principle, all interested parties can express their interest in joining the TWGs or the Forum. The access is open and the selection starts with an expression of interest procedure which is managed by the Unit C4 of DG Environment. This is why there is a relatively large number of sectoral TWGs, encompassing more than 350 representatives, working on the various BREFs, of which more than 30 have already been endorsed. The Forum participants ${ }^{8}$ vary between 90 and 100, whereby the majority of more than 50 are type $\mathrm{C}$ corporate experts next to the 28 experts from the member states (type D). There are about 10 type E experts observers from the candidate and associated to the EU countries. The access to the exert group is thus open and not formally restricted, but experts must be knowledgeable about industrial emissions and be able to evaluate the underlying industrial installations and production processes. This is a serious hurdle for environmental NGOs, which are not able to collect data comprehensively, especially not about all member states. This is why the NGOs

\footnotetext{
${ }^{8}$ Eropean Commission, 2018

(http://ec.europa.eu/transparency/regexpert/index.cfm?do=groupDetail.groupDetail\&groupID=2611)
} 
join forces and are represented by one umbrella NGO - the European Environmental Bureau (EEB). According to DG Environment, the EU-wide NGO platforms which aim to influence the decision-making process have acquired certain specialisation in order to concentrate resources and accumulate sufficient knowledge and expertise (Interview no. 4). Industrial emissions are thus "covered" by the EEB. Indeed, this is the NGO present at all ten Forum meetings conducted so far. For seven of them, it is the only NGO, while for three of them it is joined by the Climate Action Network (CAN Europe).

The main line of contestation in the expert group is between the environmentally progressive and the environmentally conservative coalition (Interview no. 4). These are not homogenous groups, as beyond the traditionally protective NGOs environmentally progressive positions are defended also by several Northern European member states and also by the representatives of the industrial sector which have invested in expensive state-of-the art environmentally-friendly production technologies and smaller industrial emissions processes. Assessed from a purely quantitative perspective, this coalition has fewer members than the coalition advocating for the preservation of the status quo. However, the process is not strongly influenced by this numerical headcount because neither the TWG nor the Forum use voting to take decisions. On the contrary, expert discussions are often geared toward finding a middle ground between the progressive and the conservative coalitions. Moreover, only robustly documented evidence is considered, regardless of the source. Hence, the quantitative disparity in this EG is not seen as a disadvantage for the environmentally progressive coalition (Interview no. 4).

According to the Commission (2018), the BREFs are "determined in a transparent manner, based on sound techno-economic information.” Indeed, the process is entirely based on documents and verifiable data, which can be and are challenged within the TWG discussions. The chances for the Commission to be misled are minimal because in the process of open deliberations among such a large group of experts, potential inaccuracies are cancelled out (Interview no. 4). The middle-ground identified after the TWG expert discussions is spelled out by the EIPPCB and incorporated in the part of the draft BREFs which is labelled "under consensus." All dissenting views are reported under the part of the document labelled "split views." The BREF is then submitted to the IED Article 13 Forum, which is required to provide its opinion to the Article 75 committee no later than eight weeks prior to the meeting of the committee. 
As already mentioned, the main function of the Forum discussions is to generate the broadest possible consensus to underpin the draft BREF, as submitted by the TWG. The discussions at this level are not technical but oriented toward finding an agreement - the Forum looks for the feasible concessions to even out the so-called "split views." When the Forum succeeds in reconciling the different views, the Commission reports the comments as "consensual within the Forum." The remaining comments are categorised as "representing the views of certain Forum members." This categorisation at the level of the TWG and of the Forum allows a single BREF to be proposed to the Article 75 committee, which votes on an implementing act that incorporates it. Given the open access to the expert group and the ensuing heterogeneity of views, it is only via robust documentation of the lines of agreement and disagreement that the process of contestation can be feasibly managed. The nonconsensual comments are annexed to the opinion of the Article 13 Forum and offered to the Article 75 committee. Moreover, the opinion of the Forum is publicly available, and minutes ${ }^{9}$ are kept of every meeting.

\subsection{High Contestation and Strategic Use of Expertise}

Overall, referring to the conceptualisation of Metz (2013, 2015) about problem-solving, substantiating and consensus-building uses of expertise, the two case studies show a frequent interplay between the different uses. In the finance case study (Expert Group E03485), we observe some problem-solving use: the experts' factual and practical knowledge of sustainable finance products was used when drafting the EG's recommendations. Intertwined with this use, we find substantiating use to achieve greater market harmonisation. The very selection of experts with more moderate views when the HLEG was set up limited the range of debated views and policy options to more modest measures which help to expand the single market in finance with a new range of sustainable finance products and working methods, but which do not require a big revision of the status quo. This indicates a consensus-building use of expertise intertwined with the substantiating one.

The use of expertise in the IED Article 13 Forum (or Expert group E02611) is also of mixed nature. In the case of the IED Article 13 Forum (Expert Group E02611), the

\footnotetext{
${ }^{9}$ Available from the Register of Commission Expert Groups at: http://ec.europa.eu/transparency/regexpert/index.cfm?do=groupDetail.groupDetail\&groupID=2611, accessed in March 2018
} 
predominant use of expertise is for consensus-building, but the problem-solving use is prevalent in the TWGs. In fact, the TWGs are the core arena of the discussions requiring technical expertise, while the Forum aims to clarify and to achieve the broadest possible consensus alongside the draft BREF proposed by the TWG. If compared to the vertical negotiations in the Council of the European Union, the work of the Forum is similar to the political role of COREPER (Interview no. 4), while the Technical Working Group (TWG) functioning under the Forum and chaired by the EIPPCB - conducts the detailed and more technocratic expert analysis.

\section{Conclusion}

Some level of acknowledgment that expertise has a political function or that "the technical is political" (Bijker et al., 2009; see also Weiss, 1979; Schrefler, 2010) has always been present in social science scholarship. The post-truth debates have emphasized and mainstreamed such claims and pointed to the interconnectedness between the instrumental and strategic uses of expert advice in the practice of public administrations. This chapter examined how the central technocratic institution of the EU - the European Commission - has sought to better legitimise its usage of expertise, considering the mobilization by some politicians of the message that experts are strategically used by policy-makers to justify political choices and the resulting policy does not respond to the concerns of the "ordinary citizen." While the Commission is still searching for the right mix between a technical and a political use of expertise in its advisory structures, our analysis shows that experts continue to play an important problemsolving role in the European policy process.

We investigated one important line of contestation of expert advice, namely, that expert groups are more responsive to corporate interests, compared to other stakeholders. The main finding is that neither at the macro nor at the micro level of analysis was there decisive evidence of "corporate capture." The macro level analysis in section 3 showed that the Commission has made substantial investment in increasing the procedural transparency of the system of expert groups through implementing the new Horizontal Rules (2016), establishing a link between the Transparency Register and the Register of Expert Groups (2017), reducing the number of type A experts and rebalancing the prevalence of type $\mathrm{B}$ and $\mathrm{C}$ experts. These efforts aim to enhance the transparency of the expert groups' work and to address critiques about experts making decisions "behind closed doors." Relating our findings to more general studies of organisational change in the EU, our results confirm the thesis of Moodie (2015, p. 
236) that the Commission is responsive toward the policy environment and pro-actively adapts to new challenges, such as the greater structural contestation of expert advice. Nevertheless, the adjustment approach is rather formal and aims to keep the established models and administrative routines. The observed adjustments are in line with what Boswell (2008) has labelled a "reinterpretation strategy," namely, reform measures which do not introduce a thorough in-depth revision of administrative practices, routines and internal working processes and, thus, do not affect the "deep core" of an organisation's set-up and operations.

Furthermore, the micro level analysis in the two case studies of section 4 showed that there is a reliance on a more strategic (consensus-building) use of expertise, which helped to narrow down the range of viewpoints and, consequently, the issues within the scope of the EG deliberations. Eventually, this facilitates the identification of compromises and acceptable policy solutions rather than overturning the status quo. The overall outcome of the expert groups' advice in the case studies is a gradual progress toward reaching the overarching policy goals: making the financial sector more sustainable and setting lower limits of industrial pollution.

Version: $24^{\text {th }}$ September 2018

Word count: 9,790 words (including about 1,220 references) 


\section{List of conducted interviews}

Interview no. 1 with Commission Official from the Transparency Unit (B4) of the SecretariatGeneral of the European Commission, Brussels on 22 January 2018

Interview no. 2 with Commission Official from the Institutional Affairs Unit (B2) of the Secretariat-General of the European Commission, Brussels on 22 January 2018

Interview no. 3 with representative of the Alliance for Lobbying Transparency and Ethics Regulation (ALTER-EU), Skype interview on 1 February 2018

Interview no. 4 with Commission Official from Industrial Emissions Unit (C4) of the DG Environment of the European Commission, Telephone interview on 23 March 2018

\section{References}

ALTER-EU (2008). Secrecy and Corporate Dominance: A Study on the Composition and Transparency of Commission Expert Groups. Brussels.

ALTER-EU (2013). A Year of Broken Promises: Big Business Still Put in Charge of EU Expert Groups Despite Commitment to Reform. Brussels.

ALTER-EU (2016). Public interest groups demand consultation on weak new rules for EU advisory groups. Open letter to Vice-President Frans Timmermans from 23.02.2016. Brussels

Ambrus, M., Arts, K., Hey E., Raulus, H. (2014). Setting the scene, Chapter 1. In: Ambrus, M., Arts, K., Hey E., Raulus, H. (Eds.) The Role of 'Experts' in International and European Decision-Making Processes. Cambridge: Cambridge University Press.

Barbier, E. (2011). The policy challenges for green economy and sustainable economic development, in: Natural Resources Forum 35, pp. 233-245.

Bijker, W., Hendriks, R., Bal, R. (2009). The Paradox of Scientific Authority. Boston: MIT Press.

Blomeyer and Sanz (2015). Composition of the Commission's Expert groups and the Status of the Register of Expert Groups. Directorate-General for Internal Policies, Budgetary Affairs, European Parliament, Brussels: September 2015

Boswell, C. (2008). Evasion, Reinterpretation and Decoupling: European Commission Responses to the 'External Dimension' of Immigration and Asylum. West European Politics, 31(3), 491-512.

Chalmers, A. (2014). Getting a Seat at the Table: Capital, Capture and Expert Groups in the European Union. West European Politics, 37(5), 976-992. 
Craft, J. and Howlett, M. (2013). The dual dynamics of policy advisory systems: The impact of externalization and politicization on policy advice. Policy and Society, 32, 187-197.

Egeberg, M. (2016). The European Commission. In M. Cini and N. Pérez-Solórzano Borragán (Eds.), European Union Politics (pp. 123-137). Oxford: Oxford University Press.

European Commission (2010). Commission Expert Groups: Horizontal Rules and Public Register (C(2010) 7649 final from 10 November 2010). Brussels

European Commission (2016a). Framework for Commission Expert Groups: Horizontal Rules and Public Register (C(2016) 3300 final from 30.05.2016). Brussels

European Commission (2016b). Commission Decision of 30.05.2016 establishing horizontal rules on the creation and operation of Commission expert groups $(\mathrm{C}(2016) 3301$ final from 30.05.2016). Brussels

European Commission (2016c). Call for applications for the Selection of Members of the High-Level Expert Group on Sustainable Finance. Retrieved from: http://ec.europa.eu/transparency/regexpert/index.cfm?do=groupDetail.groupDetailDoc\&id $=29579 \&$ no $=1$

European Commission (2016d). Decision of 28.10.2016 on the creation of a High-Level Expert Group on Sustainable Finance in the context of the Capital Markets Union. Retrieved from: https://ec.europa.eu/info/system/files/161028-decision_en.pdf.

European Commission (2016e). Rules of Procedure of the High-Level Expert Group on Sustainable Finance. Retrieved from:

http://ec.europa.eu/transparency/regexpert/index.cfm?do=groupDetail.groupDetailDoc\& $i$ $d=30181 \&$ no $=1$.

European Commission (2018). More Information on the European IPPC Bureau (EIPPCB) Prepared by the Joint Research Centre. Retrieved from: http://eippcb.jrc.ec.europa.eu/about/more_information.html.

European Ombudsman (2014). Decision of the European Ombudsman in her strategic inquiry OI/6/2014/NF concerning the composition and transparency of European Commission expert groups from 14 November 2017.

European Ombudsman (2016). Recommendation of the European Ombudsman in her strategic inquiry OI/6/2014/NF concerning the composition of Commission expert groups from 29 January 2016.

Gillet, F. (2017). 'Nigel Farage mocked for blasting world health experts as 'bullies' over smoking warning...' Evening Standard, Retrieved from:

https://www.standard.co.uk/news/uk/nigel-farage-mocked-for-blasting-world-healthexperts-as-bullies-over-smoking-warning-a3688431.html (last accessed 24 February 2018).

Gornitzka, A. and Sverdrup, U. (2008). Who Consults? The Configuration of Expert Groups in the European Union. West European Politics, 31(4), 725 - 750.

Gornitzka, A. and Sverdrup, U. (2011). Access of Experts: Information and EU Decisionmaking. West European Politics, 34(1), 48-70. 
Gornitzka, A. and Holst, C. (2015). The Expert-Executive Nexus in the EU: An Introduction. Politics and Governance, 3(1), 1-12.

Grundmann, R. and Stehr, N. (2011). The Knowledge and Power of Expertise. London: Routledge.

Hartlapp, M. (2015) Politicization of the European Commission: When, How, and with What Impact? In M. Bauer, M. and J. Trondal (Eds.), The Palgrave Handbook of the European Administrative System. European Administrative Governance. London: Palgrave Macmillan.

Hartlapp, M., Metz, J., \& Rauh, C. (2014). Which policy for Europe? Power and conflict inside the European Commission. Oxford: Oxford University Press.

Herwig, A. (2014) Health risks, Experts and Decision-Making with the SPS Agreement and the Codex Alimentarius, Chapter 10. In M. Ambrus, K. Arts, E. Hey and H. Raulus (Eds.), The Role of 'Experts' in International and European Decision-Making Processes. Cambridge: Cambridge University Press.

High-Level Expert Group on Sustainable Finance (HLEG) (2017). Interim Report. Retrieved from: https://ec.europa.eu/info/sites/info/files/170713-sustainable-finance-report_en.pdf.

High-Level Expert Group on Sustainable Finance (HLEG) (2018). Final Report. Retrieved from: https://ec.europa.eu/info/publications/180131-sustainable-finance-report_en.

Jeucken, M. and Bouma, J.J. (2001). The changing environment of banks. In J.J. Bouma, M. Jeucken and L. Klinkers (Eds.), Sustainable Banking - The Greening of Finance (pp.2438). Sheffield: Greenleaf Publishing.

Koutalakis, C., Buzogany, A. and Boerzel, T. (2010). When Soft Regulation is Not Enough: The Integration Pollution Prevention and Control Directive of the European Union. Regulation \& Governance, 4, 29-344.

Mance, H. (2016). 'We have had enough of experts, says Gove' Financial Times, available online https://www.ft.com/content/3be49734-29cb-11e6-83e4-abc22d5d108c (last accessed 24 February 2018).

Metz, J. (2013). Expert groups in the European Union: A sui generis phenomenon? Policy and Society, 32(3), 267-278.

Metz, J. (2015). The European Commission, Expert Groups, and the Policy Process: Demystifying Technocratic Governance. Palgrave MacMillan.

Moodie, J.R. (2016). Resistant to Change? The European Commission and Expert Group Reform. West European Politics, 39(2), 229-256.

Larsson, T. (2003). Precooking in the European Union: The world of expert groups, A report to ESO, the Expert Group of Public Finance. Ministry of Finance.

Larsson, T. and Murk, J. (2007). The Commission's relations with expert advisory groups. In T. Christiansen and T. Larsson (Eds.), The Role of Committees in the Policy-Process of the European Union - Legislation, Implementation and Deliberation. Cheltenham: Edward Elgar. 
Nichols, T. (2017). The Death of Expertise: The Campaign Against Established Knowledge and Why it Matters. Oxford: Oxford University Press.

Princen, S. and Rhinard, M. (2006). Crashing and creeping: agenda-setting dynamics in the European Union. Journal of European Public Policy, 13(7), 1119-1132.

Radulova, E. and Mkheidze, M. (2015). The Juncker Commission: an institutional gamechanger? pp. 29-42 in: G. Voerman, \& J. van der Harst (Eds.), De Commissie-Juncker: laatste kans voor Europa? Tussenbalans na een jaar. The Hague: Montesquieu Iinstituut.

Rasmussen, A., \& Gross, V. (2015). Biased access? Exploring selection to advisory committees. European Political Science Review, 7(3), 343-372.

Register of European Commission Expert Groups and Other Similar Entities (2018). HighLevel Expert Group on Sustainable Finance. Retrieved from: http://ec.europa.eu/transparency/regexpert/index.cfm?do=groupDetail.groupDetail\&groupI $\mathrm{D}=3485 \&$ NewSearch $=1 \&$ NewSearch $=1$

Rimkute, D., \& Haverland, M. (2015). How does the European Commission use scientific expertise? Results from a survey of scientific members of the Commission's expert committees. Comparative European Politics, 13(4), 430-449.

Robinson-Tillett, S. (2017). Let's talk about gender, HLEG: sustainable finance doesn't happen without inclusivity. In Responsible Investor. Retrieved from: https://www.responsibleinvestor.com/home/article/lets_talk_about_sex_hleg_sustainable_finance_doesnt_happen_ without_inclusiv/

Schrefler, L. (2010). The Usage of Scientific Knowledge by Independent Regulatory Agencies. Governance: An International Journal of Policy, Administration, and Institutions, 23(2), 309-330.

Schoenberger, H. (2009). Integrated Pollution Prevention and Control in Large Industrial Installations on the Basis of Best Available Techniques - The Sevilla Process. Journal of Cleaner Production, 17, 1526-1529.

Van Ballaert, B. (2015). The Politics behind the Consultation of Expert Groups: An Instrument to Reduce Uncertainty or to Offset Salience? Politics and Governance, 3(1), $139-150$.

Weiss, C. (1979). The Many Meanings of Research Utilization. Public Administration Review, 39, 426-431.

White, M. (2016). 'Should we listen to the experts on the EU referendum?' The Guardian, available online https://www.theguardian.com/politics/blog/2016/jun/08/experts-eureferendum-michael-gove (last accessed 24 February 2018). 